\title{
Entrepreneurial orientation, environmental sustainability and new venture performance: Does stakeholder integration matter?
}

\author{
Joseph Amankwah-Amoah'; Albert Danso²; Samuel Adomako
}

Corresponding author: J.Amankwah-Amoah@kent.ac.uk

\begin{abstract}
Previous research has theorised that the link between entrepreneurial orientation (EO) and performance is mediated by environmental sustainability orientation (ESO). However, firmlevel factors that may moderate this relationship are lacking. This paper attempts to fill this gap by examining how and when EO enhances new venture performance by considering ESO as mediator and stakeholder integration as an important contingent factor. Using primary data obtained from 242 chief executive officers (CEOs)/entrepreneurs, we found that the indirect relationship between EO and new venture performance is strengthened at high levels of stakeholder integration. Theoretical and practical implications are discussed.
\end{abstract}

Keywords: Environmental sustainability orientation; entrepreneurial orientation; stakeholder integration; sustainable development; stakeholder engagement; environmental policy; new venture firms, Ghana

\footnotetext{
${ }^{1}$ Kent Business School, University of Kent, UK. Email: J.Amankwah-Amoah@kent.ac.uk

${ }^{2}$ Leicester Business School, De Montfort University, Leicester, UK. Email: Albert.danso@dmu.ac.uk

${ }^{3}$ School of Management, University of Bradford, Bradford, United Kingdom. Email: S.Adomako@bradford.ac.uk
} 


\section{Introduction}

In the past, incumbent and new ventures could afford to overlook environmental sustainability issues as a costly exercise which may yield little or no benefits. Environmental sustainability orientation (hereafter ESO) reflects "the overall proactive strategic stance of firms towards the integration of environmental concerns and practices into their strategic, tactical and operational activities" (Roxas and Coetzer, 2012, p. 464; Roxas et al., 2017; see also York, O'Neil and Sarasvathy 2016). Up until recently, it was not uncommon for environmental sustainability orientation (ESO) not to feature in a new venture business plan or strategy. In recent years, environmental sustainability has gained prominence and governments, through regulations and laws, have also forced many firms to become more environment-friendly (Criado-Gomis, Cervera-Taulet and Iniesta-Bonillo, 2017; Quan Wu and Ying, 2018; Roxas and Chadee, 2012). By being mandated by laws and regulations, small firms are often left with no option than to comply with costly guidelines and regulations, which can hamper their competitiveness. At the same time, other stakeholders including customers and non-governmental organisations (NGOs) are demanding that firms develop sustainability orientation (see Neutzling et al., 2018). In recent times, research on entrepreneurial sustainability orientation has grown exponentially not only in the entrepreneurship literature, but also across the social science disciplines including marketing, strategy and operations management (see Moyano-Fuentes et al., 2018; Varadarajan, 2017).

A noteworthy hallmark of many large corporations in the 21 st century has been adoption of environmental sustainability policies to demonstrate care for the environment (see Moyano-Fuentes et al., 2018; Schillo 2011; Varadarajan, 2017). Their desire to engage with sustainability enables market-seeking and efficiency-seeking firms to reposition themselves by addressing environmental concerns (Adams et al., 2016; Nidumolu et al., 2009). There are other principal motives for firms including reputation-seeking through being seen to be 'green' and efficiency-seeking by capitalising on government incentives such as subsidies and tax relief for sustainability-oriented initiatives. Indeed, environmental sustainability has emerged as a pivotal driver of firm innovation (Nidumolu et al., 2009). By being seen to be green and engage in sustainability issues, firms can improve their reputation and consumers' perception of their brands. However, in spite of these trends, some company executives still remain unpersuaded by the benefits of environmentally friendly activities whilst others question whether such activities could actually lead to erosion of their firm's competitive advantage and hard-won market share (Nidumolu et al., 2009). 
In spite of the burgeoning stream of research on environmental sustainability and innovation (Adams et al., 2012), the linkages between entrepreneurial orientation (hereafter EO), environmental sustainability and stakeholder integration still remain underexplored (Neutzling et al., 2018). Specifically, previous research has addressed the mediating effect of ESO on the relationship between EO and venture performance (Roxas et al., 2017); however, the conditions under which this relationship is more or less effective have not been explored. That is, we are not clear whether the integration of stakeholder issues in entrepreneurialoriented ventures helps to boost ESO and whether the effect of ESO on the performance of new ventures is improved through greater stakeholder integration. The paucity of research in this area is surprising given that such decisions made under incomplete information by new ventures are more likely to lead to misallocation of scarce resources. Accordingly, we seek to answer the following question: how does stakeholder integration moderate the indirect effect of EO on new venture performance?

The study offers several contributions to entrepreneurial orientation and environmental sustainability literatures. First, much of what we know on environmental sustainability comes from large firms and multinationals (Aykol and Leonidou, 2015; Roxas et al., 2017). Indeed, large firms are well endowed in terms of slack resources, expertise and ability to spread risk of sustainability across related activities compared with new venture firms. By focusing on whether small and resource-poor businesses that engage in sustainability orientation and stakeholder integration can firms with stronger EO to achieve an overall improved performance, our study fills a lacuna in the literature on environmental sustainability and entrepreneurial orientation (Wiklund, 1999; Wiklund and Shepherd, 2005). Thus, we add to the limited literature on EO and ESO of small businesses in developing countries.

In addition, although a plethora of past studies have suggested a need for firms to adopt ESO (Roxas et al., 2017; Roxas and Chadee, 2012), we lack a solid understanding of whether the integration of stakeholder issues can enhance the indirect effect of EO on new venture success. In this direction, this study contributes to the literature by testing whether such an approach leads to improved performance. Furthermore, there is an overwhelming emphasis on activities of firms in developed countries on entrepreneurial orientation and environmental sustainability. Given that firms in emerging economies often lack legitimacy and operate under different underdeveloped institutional environments, insights from developed countries' firms offer limited or no useful insight (Roxas et al., 2017). This study contributes to the current literature on ESO by focusing on an emerging economy. 
The rest of the paper is organised as follows. We begin by reviewing the relevant literature on EO and ESO. Based on the review, we derive our hypotheses. We then explain our research method and approaches to data collection and analysis. The penultimate section outlines the key findings from our test. The theoretical and practical implications for entrepreneurship and innovation are then examined.

\section{Theoretical background and hypotheses}

\subsection{Entrepreneurial orientation}

EO originates from the strategic choice literature (Child, 1972) which encompasses firm-level policies and practices that allow a firm to take advantage of entrepreneurial opportunities (Lumpkin and Dess, 1996). EO focuses on an organisation's strategic posture reflecting proactiveness, innovativeness and risk taking (Covin and Slevin 1989). Innovativeness denotes a firm's propensity to engage in new ideas in order to activate a process that results in new products, services or technological progress (Covin and Slevin, 1991). Proactiveness reflects a high-level, opportunity-seeking behaviour that shows a firm is ahead of its competitors with an anticipation of future customer demands. Risk taking represents a practice of taking action in unknown business areas and/or the commitment of significant resources to business activities which might have uncertain consequences (Lumpkin and Dess, 2001).

Broadly, EO research shows that EO relates to firm performance (Lee et al., 2001; Rauch et al., 2009; Wiklund and Shepherd, 2005). As such, EO is an important firm capability (Alvarez and Busenitz, 2001; Lumpkin and Dess, 1996) that helps small firms to achieve sustained competitive advantage (Wiklund and Shepherd, 2003). These capabilities include the provision of skills to equip the organisation to be able to utilise its internal resources and exploit external resources (Wiklund and Shepherd, 2003). For example, a firm's proactiveness enables it to identify and generate resources to support its strategic business trajectory (Roxax et al., 2017). Similarly, it has been suggested that small resourceconstrained firms need to be innovative by integrating environmentally friendly corporate policies into their overall strategic goals (Martín-Tapia et al., 2010). Hence, EO is an important strategic orientation for a small firm's ESO development.

\subsection{Environmental sustainability orientation}

A new venture's environmental sustainability orientation decisions do not emerge out of a vacuum but rather are a reflection of the expertise and resources possessed by that venture 
that drive such a decision (Goncalves et al., 2016). The natural resource-based view (NRBV) (Hart, 1995) argues that an organisation can concurrently carry out its functions in an environmentally friendly manner and still achieve superior performance. Past studies indicate that it pays to be green for some firms (Hart and Ahuja, 1996). By implementing environment-friendly policies and introducing such products, firms are more likely to improve their efficiency, leading to development of a superior source of competitive advantage (Hart, 1995; Aragón-Correa and Sharma, 2003). By eliminating and recycling waste, firms stand a better chance of achieving stakeholder integration whilst concurrently improving their competitiveness.

The sections that follow present arguments leading to the derivation of the hypotheses. That is, the following sections examine the potential moderating role of stakeholder integration on the relationship between EO and ESO. In addition, they present arguments leading to the view that the relationship between ESO and new venture performance is moderated by stakeholder integration. Figure 1 below presents the conceptual model and hypotheses of the study.

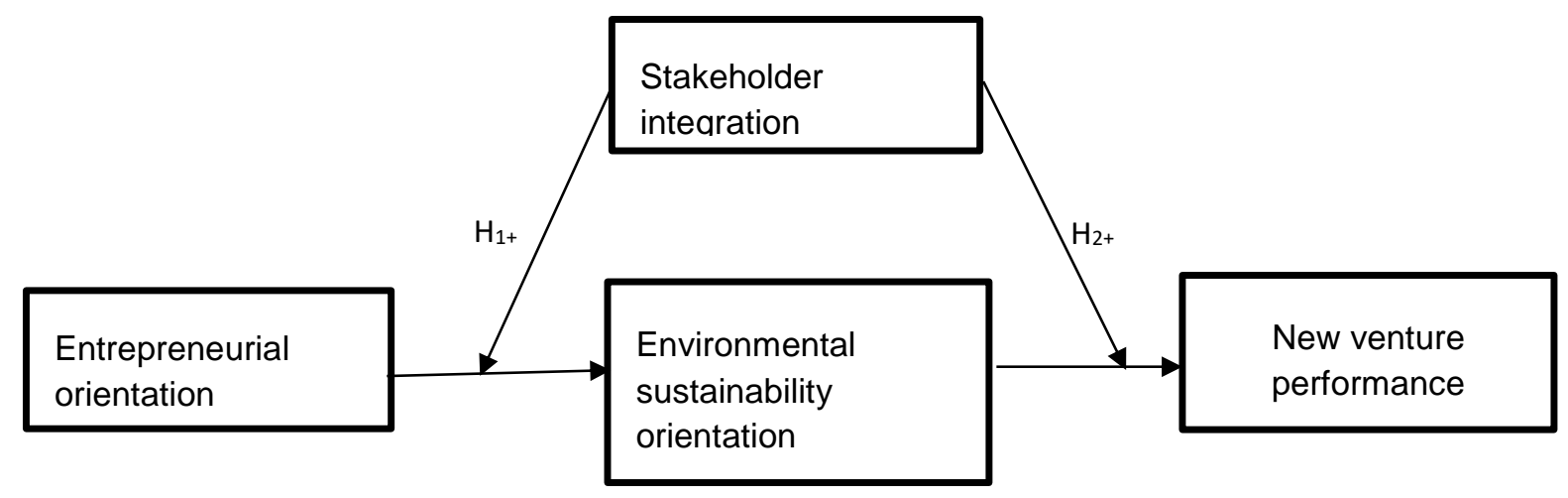

Figure 1: Conceptual model of the study

\subsection{Potential moderating effect of stakeholder integration}

Past studies have demonstrated that resource constraints such as shortage of skilled employees and institutional obstacles such as legal and regulatory restrictions and inadequate infrastructure can greatly curtail innovation and activities of small and medium-sized enterprises (SMEs) (Pissarides, 1999; van Burg et al., 2012). Indeed, lack of financial resources inhibits a firm's ability to explore new ideas to innovate (De Carolis, Yang, Deeds 
and Nelling, 2009) and achieve greater viability (Eisenhardt and Schoonhoven, 1996). Nevertheless, some studies indicate that the resource constraints faced by firms can actually force them to innovate (Hoegl, Gibbert and Mazursky, 2008). Given that resource constraints are highly impactful in emerging economies, there is a strategic imperative for SMEs to identify a niche to enhance their chances of success. One effective mechanism for such firms to enhance their competitiveness and achieve visibility is through stakeholder engagement and ESO. Such strategic orientation helps them to not only draw on key stakeholders' experiences and insights, but also develop and design products more in tune with their needs. It thus follows that an even tighter relationship between a firm and its stakeholders would not only lead to innovation but also a much improved performance (see Nidumolu et al., 2009). This is important given that such alignment is more likely to lead to first-mover advantage and minimise mismatches between stakeholders' requirements and firm's expectations. Based on the above analysis, we propose that:

H1: The positive effect of EO on ESO will become more positive when stakeholder integration is greater.

Given that new venture firms experience liabilities of newness and smallness (Stinchcombe, 1965), which limits their ability to obtain and utilise resources, these might curtail their environmental sustainability drive. In the cases of emerging markets, such firms also experience the so-called 'liability of origin' (Amankwah-Amoah and Debrah, 2017), where their geographical location can actually become a liability which curtails their ability to collaborate with other firms and access scarce resources and expertise. It has been well established that new ventures are often characterised by lack of highly skilled workforce and financial resources, which reduces their ability to innovate (Díaz-Díaz et al., 2008). It follows that small and medium-sized enterprises (SMEs) might lack the necessary human and financial capital to engage in sustainability-related issues, which can erode or undermine a firm's performance (Roxas at el., 2017). However, the resource constraints can also serve as an incentive which forces such firms to become more innovative and frugal in using their limited resources (Mosakowski, 2002). Accordingly, stakeholder engagement may enable SMEs to accrue benefits to such an extent that it may help them to offset any limitation stemming from the lack of key financial and managerial resources needed to achieve business success. Accordingly, we hypothesis that: 
H2: The positive effect of ESO on new venture performance will become more positive when stakeholder integration is greater.

\section{Research method}

\subsection{Research context}

The hypotheses were tested using a sample of SMEs in Ghana, an emerging sub-Saharan African nation. Ghana was used as the research setting for many reasons. First, Ghana has successfully implemented a sound economic transformation and an open market policy for more than three decades, offering a rich contextual setting for examining how Western market theories apply to emerging market settings. Second, Ghana has practised democracy since 1992, making the country a valued place for foreign direct investment in West Africa (World Bank, 2011). Third, since the early 2000s, the country has initiated a host of market and industrial reforms aimed at encouraging businesses to adopt environmentally friendly measures including recycling of waste, and protecting local forest and rivers. The government has also imposed restrictions on importation or exploration e-waste to create incentives for firms to recycle. The country is also considered as a representative of emerging economies in West Africa (Julian and Ofori-Dankwa, 2013), providing a conducive business environment in which to test the hypotheses.

\subsection{Sample and data sources}

The sampling frame of the study was derived from the Ghana Business Directory and Registrar General's Department databases (Acquaah, 2007). In total, 1,200 manufacturing SMEs (650 businesses from a total of 11,000 in the Ghana Business Directory database and 550 businesses from a total of 14,000 in the Registrar General's Department database) were randomly contacted via telephone to ask for their participation in the study. The 1,200 SMEs sampled were those that met the Ghana Statistical Service's criteria for SMEs (Ghana Statistical Service, 2000). Using these criteria, only SMEs employing a minimum of five and fewer than 250 employees and with an annual turnover below US\$20 million were considered. These criteria are in line with extant entrepreneurship studies (Adomako et al., 2016; Cardon and Kirk, 2015). Four hundred and fifty-five (455) SMEs (37.9\%) agreed to take part in the study.

The data collection was carried out in two waves. First, all the 455 SMEs were contacted with a hand-delivered questionnaire. Only CEOs/entrepreneurs were asked to 
provide responses to the questionnaire. After several rounds of reminders, a total of 319 complete responses were received. This represents a $70.10 \%$ response rate. To ensure that only the CEO/entrepreneur completed the questionnaire, we took a sample of the completed questionnaire and contacted them via telephone.

To attenuate the possibility of common variance influencing the integrity of the data (Podsakoff, et al., 2003), the second phase of the data collection took place six months after the first survey. This time, finance managers from the 319 SMEs were approached in person with another questionnaire to tap firm performance. After sending three reminders, a total of 250 complete responses were received from the finance managers of the SMEs $(78.36 \%)$. After matching the first survey with the second survey, it was detected that eight of the CEOs/entrepreneurs were also the finance managers. As such, those eight questionnaires were discarded. Hence, 242 complete responses across Time 1 and Time 2 were used for the analysis. This represents a 53.18\% effective response rate (i.e. [242/455] x 100).

On average, the firms employed 66 full-time employees. Their average prior growth rate was $11.22 \%$. Again, on average, they had been in business for seven years since their inception. To investigate the possibility of non-response bias, the early and late respondents were compared in terms of firm age, size and growth rates. Since no significant differences were found between these two groups, it was concluded that non-response bias did not influence the data (Armstrong and Overton, 1977).

\subsection{Measures}

All the constructs that measured the dependent and independent variables were taken from previous studies. The items were measured on a seven-point Likert scale ranging from $1=$ strongly disagree to $7=$ strongly agree.

\subsubsection{Entrepreneurial orientation}

Entrepreneurial orientation $(\alpha=95)$ was measured by adopting Covin and Slevin's (1989) nine-item scale which captures a firm's degree of innovation (new product introduction), risk taking (proclivity to take high risk) and proactiveness (strategic actions considered as bold and wide-ranging). This study followed previous studies (e.g., Covin and Slevin, 1989; Miller, 1983) and adopted the composite dimension approach to define a firm's EO. This approach suggests that three dimensions work together and that a venture is considered entrepreneurial when it exhibits high risk taking, proactiveness and innovative behaviour collectively. 


\subsubsection{Environmental sustainability orientation}

Environmental sustainability orientation was captured by using the three-dimensional scale entailing knowledge about environmental sustainability, environmentally sustainable practices and commitment to environmental sustainability (Roxas, Ashill and Chadee, 2017). A firm's knowledge about sustainability was measured with five items whilst its environmentally sustainable practices were captured with eight items. A firm's commitment to environmental sustainability was tapped with four items. A composite of the three dimensions constitutes the variable score for environmental sustainability orientation $(\alpha=95)$.

\subsubsection{Stakeholder integration}

Stakeholder integration was conceptualised as a three-dimensional construct, entailing firms' knowledge of stakeholders, interaction with stakeholders and adaptation to stakeholder demands (Plaza-Úbeda, de Burgos-Jiménez and Carmona-Moreno, 2010). A firm's knowledge of its stakeholders was measured with four items. Similarly, four items captured its level of stakeholder interaction. Finally, five items tapped its adaptation to stakeholder demands. The stakeholder integration scale $(\alpha=.90)$ is the mean value of the composite measures of knowledge of stakeholders, interaction with stakeholders and adaptational behaviour.

\subsubsection{New venture performance}

Seven subjective items captured new venture performance (e.g., Luk et al., 2008; Sheng, Zhou and Li, 2011). Respondents were asked to compare their firms with their competitors in the industry in the last three years. A composite of the seven items yielded excellent reliability $(\alpha=.97)$. Subjective performance measures were used due to difficulties in obtaining objective accounting data in emerging economies (Hoskisson, et al., 2000). The use of subjective performance measures is appropriate given that "CEO perception of performance can be regarded as an important independent variable in and of itself" (Powell, 1992, p.125).

\subsubsection{Control variables}

This study included four control variables to account for their effects on the dependent variables. These were firm size, firm age, market scope and prior venture growth. First, firm size was measured as logarithm transformation of number of full-time employees (Sheng, Zhou and $\mathrm{Li}$, 2011). Second, firm age was measured as logarithm transformation of the number of years since the business was incepted (Akgün et al., 2012). Market scope was controlled for as a dummy variable ( $0=$ local; $1=$ international). Finally, since previous studies 
indicate that prior growth influences venture growth (Baum and Locke, 2004), this study controlled for this variable. This study followed Baum and Locke (2004) and calculated prior growth as the percentage change in sales and employment between 2014 and $2016=$ [(2014/2016)-1].

\subsection{Validity and reliability tests}

Prior to the confirmatory factor analysis, several tests were conducted to assess the possibility of common method bias influencing the integrity of the results. First, a Harman's (1967) onefactor test was conducted. To do this, all the self-reported measures were entered in exploratory factor analysis (EFA) using the principal factoring and varimax rotation. Ten factors emerged with eigenvalues larger than 1, together accounting for $83.33 \%$ of the total variance, with the first factor accounting for $23.14 \%$. This indicates that common-method variance is not a threat to the integrity of the results.

Nevertheless, Harman's (1967) one-factor test is inconclusive, hence this study utilised the procedure recommended by Cote and Buckley (1987) and estimated three competing common method bias nested models (Table 1). Model 1 examined the 'trait-only' model, allowing all the indicators to load on a single latent factor. In Model 2, the 'methodonly' model was estimated where each indicator was allowed to load on its respective latent factor. Finally, Model 3 introduced a 'trait and method' model. This model combined models 2 and 3 where a common factor links all the indicators in Model 2. When the goodness-of-fit heuristics were inspected, models 2 and 3 showed a better fit than Model 1. In addition, Model 3 did not perform substantially better than Model 2. These results suggest that common method variance does not influence the results of the study.

Table 1: Common Method Bias Nested Models: Goodness-of-fit Statistics

\begin{tabular}{|c|c|c|c|c|c|c|c|c|c|}
\hline Model & $\chi^{2}$ & df & $\chi^{2} / \mathrm{df}$ & RMSEA & CFI & NNFI & NFI & GFI & SRMR \\
\hline Model 1: Trait & $2454.85 * * *$ & 869 & 2.58 & 0.23 & 0.32 & 0.33 & 0.40 & .55 & 0.03 \\
\hline $\begin{array}{l}\text { Model 2: } \\
\text { Method }\end{array}$ & $1629.30 * * *$ & 825 & 1.97 & 0.04 & 0.93 & 0.95 & .97 & .92 & 0.05 \\
\hline $\begin{array}{l}\text { Model 3: Trait- } \\
\text { method }\end{array}$ & $1358.15 * * *$ & 1004 & 1.35 & 0.02 & .96 & .97 & .98 & .96 & 0.05 \\
\hline
\end{tabular}

$* * * p<.001 . \mathrm{df}$, degrees of freedom; RMSEA=Root mean square error of approximation; CFI=Comparative fit index; NNFI=Non-normed fit index; NFI=Normed fit index; GFI=Goodness-of-fit index; SRMR= Root mean square error of approximation

Subsequently, discriminant validity of the variables was investigated prior to hypotheses testing. Though the variables examined in the current study are theoretically different, a 
confirmatory factor analysis (CFA) was performed using LISREL 8.5 software package with the maximum likelihood approach. The square roots of the average variance extracted (AVE) for each construct were calculated and inspected. This approach allows the establishment of empirically discriminant validity of the variables.

In constructing the CFA, first a one-factor model and a two-factor model were formed. The model fit of each model was inspected using the chi-square difference test to establish which of the models provides a better fit for the data. Results from the CFA show that Model 2 (two-factor model) entailing EO and ESO fits the data excellently $\left(\chi^{2} / \mathrm{df}=3.42\right.$; RMSEA=.03; CFI=.95; GFI=.97; NFI=.91; SRMR=.05). The one-factor model produced the following fit heuristics $\left(\chi^{2} / \mathrm{df}=7.33 ;\right.$ RMSEA=.08; CFI=.73; GFI=.67; NFI=.59; SRMR=.16), suggesting that the model did not fit the data well. The results show that the chisquare difference between the two models was significant at $\mathrm{p}<.001$. Moreover, all the items in Model 2 loaded well on their respective latent variables. This suggests that Model 2 performed better than Model 1.

In addition to the discriminant validity, the Cronbach's Alpha and composite reliabilities of the measures were inspected. The results show that Cronbach's Alpha values were larger than 0.70 whilst composite reliability values exceeded 0.60 . These results provide support for the reliability of the measures used in the study (Bagozzi and Yi, 2012). Next, each factor loading was examined to establish convergent validity of the scales. Findings from the analysis indicate that each factor loading exceeded the traditional threshold value of 0.40. This shows that convergent validity was achieved in this study (e.g., Anderson and Gerbing, 1988).

Finally, the overall fit of the model was assessed using a number of fit heuristics including the chi-square $\left(\chi^{2}\right)$. The overall CFA produced excellent model fit $\left(\chi^{2} / \mathrm{df}=3.61\right.$; RMSEA $=$ $.04 ; \mathrm{NFI}=.98 ; \mathrm{NNFI}=.95 ; \mathrm{CFI}=.98 ; \mathrm{GFI}=.96 ; \mathrm{SRMSR}=.05)$. These results show the robustness of the overall fit of the measurement model.

\section{Analyses and results}

Table 2 shows the means, standard deviations and inter-construct correlations. It indicates that EO correlates positively with ESO, and ESO is positively related to new venture performance. The results of the moderated mediation analyses are presented in Tables 3 and 4. To test the hypotheses, the hierarchical regression analysis was used. To assess whether multicollinearity affects that data, the mean-centring method was adapted using all the variables involved in the interaction. The highest variance inflation factor is 2.10 for the 
moderation analysis and 3.17 for the mediation analysis. The results suggest that multicollinearity did not pose a concern in the study as the VIF values obtained are less than10 (Barringer and Bluedorn, 1999).

Table 2: Descriptive statistics and inter-construct correlations (square root of average variance extracted in diagonal)

\begin{tabular}{|c|c|c|c|c|c|c|c|c|c|c|c|}
\hline & Variables & Mean & S.D & 1 & 2 & 3 & 4 & 5 & 6 & 7 & 8 \\
\hline 1. & $\begin{array}{l}\text { Firm-size (full- } \\
\text { time employees }\end{array}$ & 66.09 & 45.22 & & & & & & & & \\
\hline 2. & Firm age $^{a}$ & 7.22 & 5.49 & $.37 * *$ & & & & & & & \\
\hline 3. & Market scope & .50 & .50 & $.22 * *$ & $.19 * *$ & & & & & & \\
\hline 4. & Prior growth & 11.22 & 2.15 & $-.15 * *$ & $-.10 *$ & -.03 & & & & & \\
\hline 5. & $\begin{array}{l}\text { Stakeholder } \\
\text { integration }\end{array}$ & 4.75 & .53 & -.06 & $.19 * *$ & $.33^{* *}$ & $.34 * *$ & $(.76)$ & & & \\
\hline 6. & $\mathrm{EO}$ & 4.12 & .81 & $.32 * *$ & $.21 * *$ & $.28 * *$ & $.19 * *$ & $.39 * *$ & $(.78)$ & & \\
\hline 7. & ESO & 5.33 & .73 & $.17 * *$ & $.14 *$ & $.11^{*}$ & $.29 * *$ & $.37 * *$ & $.34 * *$ & $(.84)$ & \\
\hline 8. & $\begin{array}{l}\text { New venture } \\
\text { performance }\end{array}$ & 4.96 & .68 & -.05 & -.06 & $.21 * *$ & $.31 * *$ & $.23 * *$ & $.26 * *$ & $.38 * *$ & $(.85)$ \\
\hline
\end{tabular}

Although no hypothesis was specified for the relationship between EO and ESO, this study found a positive and significant relationship between $\mathrm{EO}$ and $\mathrm{ESO}(\beta=25, p<.01)$. This confirms the results of extant studies in the area (e.g., DiVito and Bohnsack, 2017; Roxas, Ashill and Chadee, 2017). Similarly, no hypothesis was proposed for the impact of ESO on new venture performance; however, this study found a positive and significant relationship between ESO and venture performance. Again, this study is consistent with other current studies (Roxas, Ashill and Chadee, 2017).

Hypothesis 1 argues for a moderating effect of stakeholder integration on the relationship between EO and ESO. The results of the hypothesis test revealed a positive and significant moderating impact of stakeholder integration on the link between ESO and SI $(\beta=.49, p<.01)$. Figure 2 presents this relationship, which indicates the effect of EO and ESO is stronger at high levels of stakeholder integration.

Hypothesis 2 predicts a moderating impact of stakeholder integration with respect to the relationship between ESO and new venture performance. As per Table 4 (Model 6), the effect of ESO and new venture performance is amplified at greater levels of stakeholder integration $\left(\beta=.55, p^{<} .01\right)$. This result offers support for Hypothesis 2. Similarly, Figure 3 
shows that, at high levels of stakeholder integration, ESO exerts stronger effects on new venture performance.

Table 3: Results of the moderation effect of EO and stakeholder integration on environmental sustainability orientation

Dependent variable: Environmental sustainability orientation $(\mathrm{N}=242)$

Independent Variables Model 1

Model 2 Model $3 \quad$ Model 4

Control variables

Firm age ${ }^{\text {a }}$ (years)

$\begin{array}{lccc}.04 & .09 * & .09 * & .08^{*} \\ .12 * & .11 * & .10^{*} & .13^{*} \\ .03 & .05 & .02 & .03 \\ -.05 & -.03 & -.04 & -.06^{*}\end{array}$

Market scope

Prior growth

$.25 * * *$

$.24 * * *$

$.16 * * *$

Entrepreneurial orientation

(EO)

Stakeholder integration (SI)

$.21 * * *$

$.20 * * *$

Moderating effect

H1: EO x SI

Model Fit Statistics

F-value

2.1

$\mathrm{R}^{2}$

.10

$7.5 * * *$

$8.9 * * *$

$9.8 * * *$

$\Delta \mathrm{R}^{2}$

2.10

.16

.27

.39

Mean VIF

${ }^{\text {a Logarithm. }}{ }^{* * *} \mathrm{p}<0.001 ; * * \mathrm{p}<0.05 ; * \mathrm{p}<0.1$

To test the notion that ESO mediates the link between EO and new venture performance, this study followed Baron and Kenny (1986). This procedure suggests that mediation is achieved when the following three conditions are met: (1) when the independent variable significantly predicts both the dependent variable and mediator variable, (2) when the mediator variable significantly predicts the dependent variable, and (3) when the mediator variable is included in the regression equation, the influence of the independent variable on the dependent variable is attenuated. This approach suggests that a full mediation is reached when the impact of the independent variable on the dependent variable is non-significant when the mediator variable is included. Conversely, a partial mediation is met when the effect of the independent variable on the dependent variable is weakened but remains significant. 
Table 4: Results of moderated mediation analysis

\begin{tabular}{|c|c|c|c|c|c|c|}
\hline \multirow[b]{2}{*}{ Independent Variables } & \multicolumn{6}{|c|}{ Dependent variable: new venture performance $(\mathrm{N}=242)$} \\
\hline & Model 1 & Model 2 & Model 3 & Model 4 & Model 5 & Model 6 \\
\hline \multicolumn{7}{|l|}{ Control variables } \\
\hline Firm age (years) & $-.06^{*}$ & $-.07 *$ & $-.09 *$ & -.05 & -.04 & $-.07 *$ \\
\hline Firm size (employees) & .03 & .02 & .05 & .04 & .05 & .03 \\
\hline Prior growth & $.11 *$ & $.12 *$ & $.13 * *$ & $.11 *$ & $.12 *$ & $.13 * *$ \\
\hline Market scope & $.08 *$ & $.07 *$ & $.08 *$ & $.09 *$ & $.07 *$ & $.11 *$ \\
\hline $\mathrm{EO}$ & & $.14 * *$ & $.13 * *$ & $.14 * *$ & .03 & $.13 * *$ \\
\hline Stakeholder integration (SI) & & & $.15^{* * *}$ & $.20 * * *$ & $.16^{* * *}$ & $.18 * * *$ \\
\hline EO x SI & & & & $.25 * * *$ & $.26 * * *$ & $.25^{* *}$ \\
\hline $\begin{array}{l}\text { Environmental sustainability } \\
\text { orientation (ESO) }\end{array}$ & & & & & $.14 * *$ & $.15^{* * *}$ \\
\hline ESO x SI & & & & & $.41 * * *$ & $.39 * * *$ \\
\hline $\mathrm{H}_{2}: \mathrm{ESO} \times \mathrm{SI}$ & & & & & & $.55^{* * *}$ \\
\hline \multicolumn{7}{|l|}{ Model Fit Statistics } \\
\hline F-value & $3.5^{*}$ & $5.9 * *$ & $7.8 * * *$ & $8.2 * * *$ & $9.2 * * *$ & $9.6 * * *$ \\
\hline $\mathrm{R}^{2}$ & .11 & .18 & .27 & .39 & .48 & .52 \\
\hline$\Delta \mathrm{R}^{2}$ & - & $.07 *$ & $.09 * * *$ & $.12 * * *$ & $.09 * * *$ & .04 \\
\hline Mean VIF & 1.20 & 1.07 & 1.79 & 3.17 & 2.06 & 1.88 \\
\hline
\end{tabular}

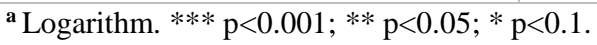

The results of the mediating effect of stakeholder integration show that (Model 6; Table 4) the effect of stakeholder integration on the relationship between EO and new venture performance is significant $(\beta=.25, p<.001)$. Table 3 also shows that there is a significant relationship between stakeholder integration-moderated EO and ESO $(\beta=.49, p<.001)$. Second, stakeholder integration-moderated ESO is significantly related to new venture performance $(\beta=.55, p<.001)$, as shown in Model 6 of Table 4 . 


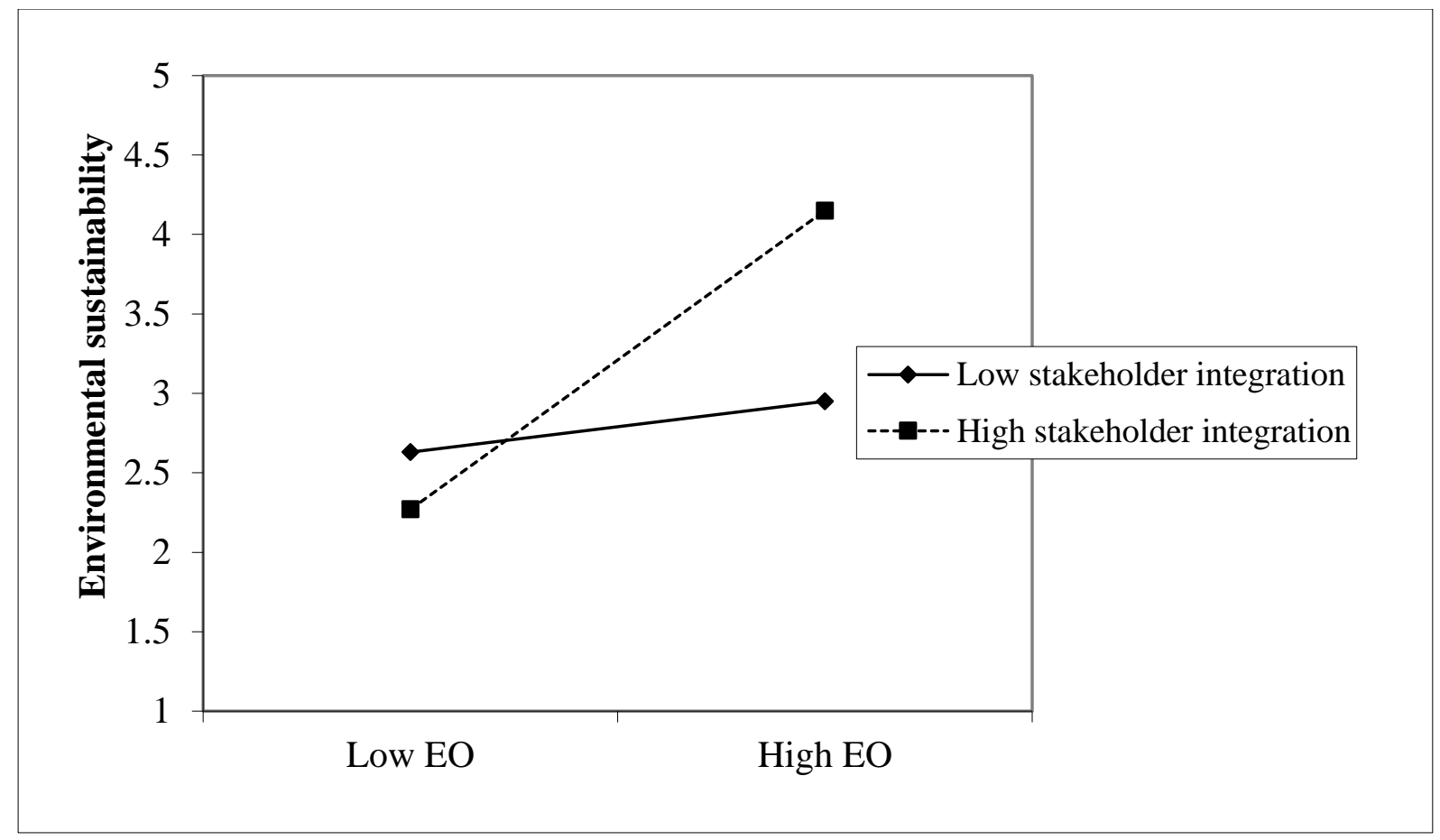

Fig. 2: Interaction effect of EO with stakeholder integration on environmental sustainability orientation

Third, as shown in Model 5 of Table 4, the regression coefficient for the effect of EO on new venture performance tends to be insignificant when EO is added in the regression equation. The regression coefficient decreases from $\beta=.14, p<.05$ in Model 2 to $\beta=.03$, n.s in Model 5. This suggests that ESO fully mediates the positive link between EO and new venture performance in this study. To establish the robustness of the mediation test, this study used the Sobel test (Sobel, 1982) to calculate the quantum of the unstandardised indirect effect and its related standard error. The results of the Sobel test show that the indirect effect of stakeholder integration-moderated EO on new venture performance (Sobel statistic=1.33, $p<$ .05) was as expected and statistically significant. This provides further support for evidence of full mediation. 


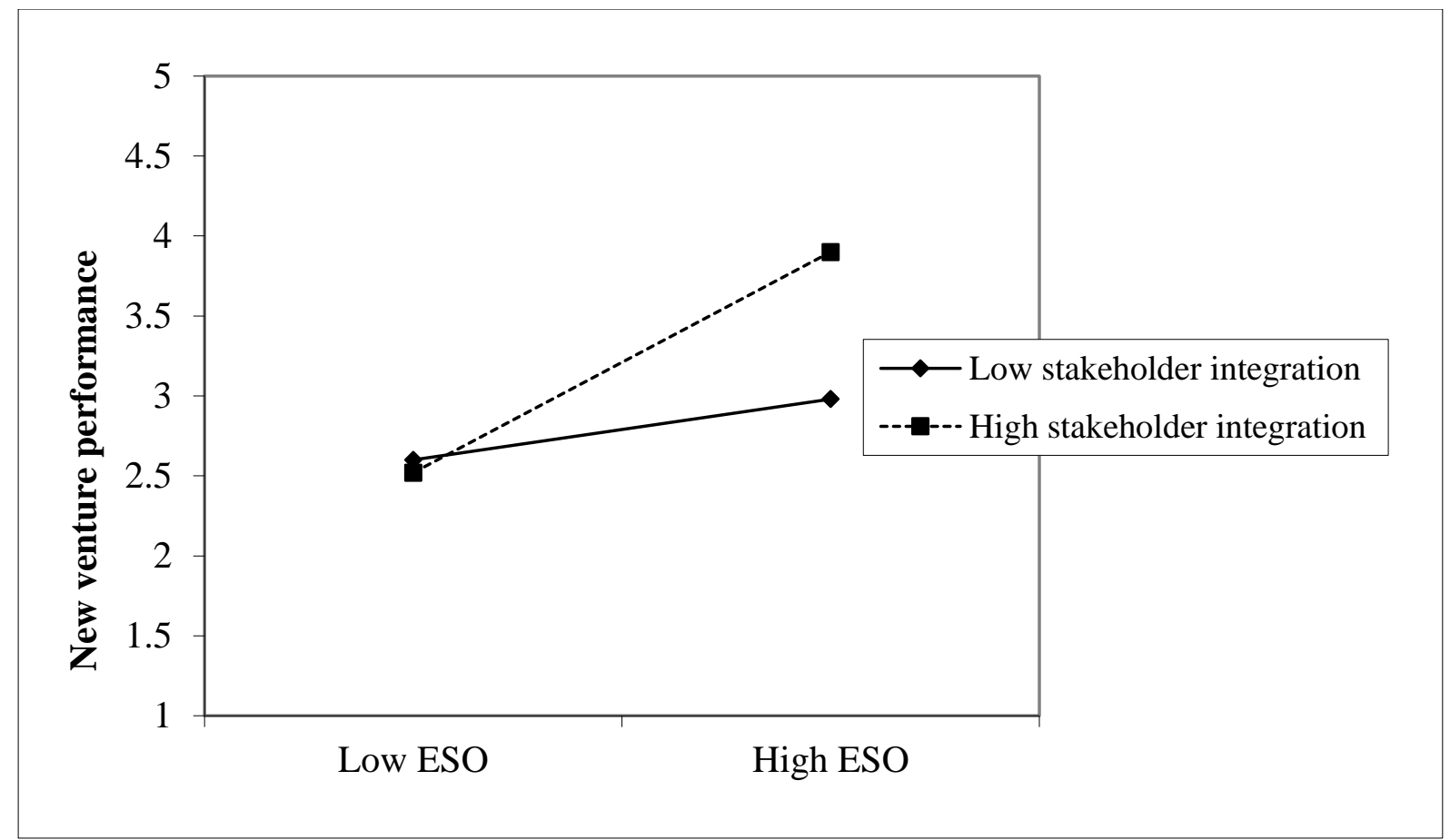

Fig. 3: Interaction effect of ESO with stakeholder integration on new venture performance 


\section{Discussion and conclusion}

The main objectives of this study were to investigate when (i.e., under what conditions) the indirect effect of EO on new venture performance is most effective. Using insights from an emerging economy, i.e. a sample of SMEs in Ghana, we found that the effect of ESO mediates the relationship between EO and new venture performance and this relationship is moderated by stakeholder integration. These findings are consistent with extant research suggesting that small businesses in developing market settings can benefit from being environmentally friendly (see Roxas et al., 2017). Our study shows the crucial enabling role of stakeholder integration in the relationship between EO and ESO, and firm performance in a developing country. These findings show that, although small firms can achieve environmental sustainability and performance when they implement EO, stakeholder integration can help entrepreneurial small firms to become environmentally sustainable and achieve even higher success in an emerging market context. Accordingly, we provide further evidence to support the theoretical contention that ESO can equip small firms to achieve superior performance and thereby enable them to enhance their organisational robustness (Hart, 1995). Given that lack of financial resources inhibits small firms' ability to explore new ideas and innovate (van Burg et al., 2012; De Carolis et al., 2009; Voss, Sirdeshmukh and Voss, 2008), ESO appears to be an effective mechanism for such firms to sidestep some of the constraints to their development in emerging markets. Given that we are in the era of transient advantage (McGrath, 2013), ESO can be viewed as an underutilised and untapped source of information and knowledge for SMEs to develop and sustain a competitive edge.

\subsection{Contributions to theory and practice}

This study theoretically extends previous research in many ways. First, the study theorises that, although EO is essential for small firms to become environmentally sustainable, stakeholder integration exerts a strong and positive force on this relationship. A dominant view is that small businesses lack the resources to pursue sustainable environmental practices, unlike large firms (Holland and Gibson, 1997). This study challenges this notion by contending that the interaction of EO and stakeholder integration exerts greater force for small firms to be environmentally sustainable in a developing country setting. Thus, this study shows that the successful implementation of EO to achieve excellent ESO requires the integration of stakeholders. Second, this study adds to prior research that examines the effect of ESO on performance (e.g., Golicic and Smith, 2013; Molina-Azorín, et al., 2009; Roxas et al., 2017). By investigating the moderating role of stakeholder integration on the ESO- 
performance linkage, this study shows firm-level conditions under which ESO is more positively related to performance. Such an interaction has anecdotally been suggested but, at present, it is not understood. In doing so, this study also contributes to the fundamental propositions of the natural resource-based view (Hart, 1995). Whilst this view highlights environmentally friendly capabilities as key sustainable business practices, the findings from this study show how small firms from developing country markets can manage their strategic orientations and firm-level capabilities to enhance firm performance. Third, the findings from this study add to scholarly efforts to understand the processes through which firms' strategic orientations such as EO and ESO ultimately impact firm-level outcomes such as new venture performance. Efforts to understand these relationships have been adjudged an important task in entrepreneurship (e.g., Aragón-Correa and Sharma, 2003; Aragón-Correa et al., 2008; Roxas et al., 2017). Results from this study contribute to this task by adding stakeholders to two strategic orientations to explain their effects on new venture performance (see also Shubham, Charan and Murty, 2018).

Beyond the implications for theory, the results show that stakeholder integration can assist SMEs to implement EO to shape their ESO for performance. The effect of EO on ESO is amplified when there are greater levels of stakeholder integration. Similarly, the impact of ESO on performance is bolstered at high levels of stakeholder integration. These findings are particularly crucial for entrepreneurial SMEs that operate in emerging market settings to understand the implications of stakeholder integration at the firm level. That is, for entrepreneurial SMEs to be environmentally sustainable and eventually achieve success in emerging market settings, this study shows that the integration of stakeholders cannot be ignored.

\subsection{Limitations and future research direction}

This study has some limitations which should be considered when interpreting the findings. First, we used a sample of SMEs in Ghana; thus, the findings should be evaluated in the context of an emerging economy. Future research may wish to examine these relationships in developed societies where firms are more resourceful in order to examine how the results from the current research change. Second, this study also focused on SMEs as the majority of businesses in Ghana fall under this category. As such, this study did not compare SMEs with large organisations to establish how these firms leverage their strategic orientations for implementing firm-wide policies towards environmental sustainability and business 
performance. A major contention is that larger firms are more resourceful and more likely to be environmentally sustainable and have a stronger stakeholder capability than SMEs. Conversely, it could be contended that SMEs are more flexible in terms of decision-making and resources, and undertake EO and ESO practices and integrate stakeholders with ease compared to larger firms. These questions are left for future studies to answer. Third, although several steps were taken to attenuate the possibility of various forms of bias, the use of perceptual measures could subject these findings to different types of bias. Future research may use objective financial data to measure firm performance. Given that emerging markets are at different stages of transition, the contextual influences (economic, cultural and political factors) and experiences of the different stakeholders might have played a role in the applicability of the findings. Future studies could explore emerging economies at different stages of transition. It is hoped that this study will help to foster new lines of research on the relationship between stakeholder integration and firm performance in Africa and other emerging economies. 


\section{References}

Adams R, Jeanrenaud S, Bessant J, Denyer D, Overy P. 2016. Sustainability-oriented innovation: a systematic review. International Journal of Management Reviews 18(2): 180-205.

Adomako S, Danso A, Uddin M, Damoah JO. 2016. Entrepreneurs' optimism, cognitive style and persistence. International Journal of Entrepreneurial Behavior \& Research 22(1): 84-108.

Akgün AE, Keskin H, Byrne J. 2012. Antecedents and contingent effects of organizational adaptive capability on firm product innovativeness. Journal of Product Innovation Management 29(S1): 171-189.

Alvarez SA, Busenitz LW. 2001. The entrepreneurship of resource-based theory. Journal of Management 27(6): 755-775.

Amankwah-Amoah J, Debrah Y. 2017. Toward a construct of liability of origin. Industrial and Corporate Change 26(2): 211-231.

Amankwah-Amoah J. 2016. The evolution of science, technology and innovation policies: A review of the Ghanaian experience. Technological Forecasting and Social Change, $110,134-142$.

Anderson JC, Gerbing DW. 1988. Structural equation modeling in practice: A review and recommended two-step approach. Psychological Bulletin 103(3): 411.

Aragón-Correa JA, Hurtado-Torres N, Sharma S, García-Morales VJ. 2008. Environmental strategy and performance in small firms: A resource-based perspective. Journal of Environmental Management 86(1): 88-103.

Aragón-Correa JA, Sharma S. 2003. A Contingent Resource-Based View of Proactive Corporate Environmental Strategy. Academy of Management Review 28(1): 71-88.

Armstrong JS, Overton TS. 1977. Estimating nonresponse bias in mail surveys. Journal of Marketing Research 5(3): 396-402

Aykol BL. Leonidou 2015. Researching the green practices of smaller service firms: A theoretical, methodological and empirical assessment. Journal of Small Business Management 53(4): 1264-1288.

Bagozzi RP, Yi Y. 2012. Specification, evaluation, and interpretation of structural equation models. Journal of the Academy of Marketing Science 40(1): 8-34.

Barringer BR, Bluedorn AC. 1999. The relationship between corporate entrepreneurship and strategic management. Strategic Management Journal 421-444.

Baum JR Locke EA. 2004. The relationship of entrepreneurial traits, skill, and motivation to subsequent venture growth. Journal of Applied Psychology 89(4): 587-598 
Cardon MS, Kirk CP. 2015. Entrepreneurial passion as mediator of the self-efficacy to persistence relationship. Entrepreneurship Theory and Practice 39(5): 1029-1050.

Cote JA, Buckley MR. 1987. Estimating Trait, Method, and Error Variance: Generalizing Across 70 Construct Validation Studies. Journal of Marketing Research 24(3): 315318.

Covin J, Slevin D. 1989. Strategic Management of Small Firms in Hostile and Benign. Environments, Strategic Management Journal 10(1): 75-87.

Covin JG, Slevin DP. 1991. A conceptual model of entrepreneurship as firm behavior. Entrepreneurship: Critical Perspectives on Business and Management 3: 528.

Criado-Gomis A, Cervera-Taulet A, Iniesta-Bonillo MA. 2017. Sustainable Entrepreneurial Orientation: A Business Strategic Approach for Sustainable Development. Sustainability, 9(9), 1667.

Criado-Gomis A, Iniesta-Bonillo MÁ, Cervera-Taulet A. 2018. Sustainable entrepreneurial orientation within an intrapreneurial context: effects on business performance. International Entrepreneurship and Management Journal, 1-14.

Dangelico RM, Pujari D. 2010. Mainstreaming green product innovation: Why and how companies integrate environmental sustainability. Journal of Business Ethics 95(3): 471-486.

De Carolis DM, Yang Y, Deeds DL, Nelling E. 2009.Weathering the storm: The benefit of resources to high-technology ventures navigating adverse events. Strategic Entrepreneurship Journal 3(2): 147-60.

Delmas M, Toffel M. 2004. Stakeholders and environmental management practices: an institutional framework. Business Strategy and the Environment 13(4): 209-222.

Díaz-Díaz NL, Aguiar-Díaz I, De Saá-Pérez P. 2008. The effect of technological knowledge assets on performance: The innovative choice in Spanish firms. Research Policy 37(9): 1515-29.

DiVito L, Bohnsack R. 2017. Entrepreneurial orientation and its effect on sustainability decision tradeoffs: The case of sustainable fashion firms. Journal of Business Venturing 32(5): 569-587.

Dolmans SA, van Burg E, Reymen IM, Romme AGL. 2014. Dynamics of resource slack and constraints: resource positions in action. Organization Studies 35(4): 511-549.

Eisenhardt KM, Schoonhoven CB. 1996. Resource-based view of strategic alliance formation: Strategic and social effects in entrepreneurial firms. Organization Science 7(2): 136-50. 
Fornell C, Larcker DF. 1981. Structural equation models with unobservable variables and measurement error: Algebra and statistics. Journal of Marketing Research 18(3): 382388.

Ghana Statistical Service. 2000. Ghana Living Standards Survey: Report of the Fourth Round (GLSS4) 1998/1999, Standard Press: Accra, Ghana.

Golicic SL, Smith, CD. 2013. A meta-analysis of environmentally sustainable supply chain management practices and firm performance. Journal of Supply Chain Management, 49(2): 78-95.

Goncalves O, Robinot E, Michel H. 2016. Does it pay to be green? The case of French ski resorts. Journal of Travel Research 55(7): 889-903.

Grichnik D, Brinckmann J, Singh L, Manigart S. 2014. Beyond environmental scarcity: Human and social capital as driving forces of bootstrapping activities. Journal of Business Venturing 29(2): 310-326.

Harman HH. 1976. Modem factor analysis. Chicago: University of Chicago.

Hart SL, Ahuja G. 1996. Does It Pay to Be Green? An Empirical Examination of the Relationship Between Emission Reduction and Firm Performance. Business Strategy and the Environment 5(1): 30-37.

Hart SL, Dowell G. 2011. Invited editorial: A natural-resource-based view of the firm: fifteen years after. Journal of Management 37(5): 1464-1479.

Hart SL. 1995. A Natural-Resource Based View of the Firm. Academy of Management Review 20(4): 986-1014.

Hoegl MM. Gibbert, Mazursky D. 2008. Financial constraints in innovation projects: When is less more? Research Policy 37(8): 1382-1391.

Hoskisson RE, Eden L, Lau CM, Wright M. 2000. Strategy in emerging economies. Academy of Management Journal 43(3): 249-267.

Julian SD, Ofori-Dankwa JC. 2013. Financial resource availability and corporate social responsibility expenditures in a sub-Saharan economy: The institutional difference hypothesis. Strategic Management Journal 34(11): 1314-1330.

Kuckertz A, Wagner M. 2010. The influence of sustainability orientation on entrepreneurial intentions-Investigating the role of business experience. Journal of Business Venturing 25(5): 524-539.

Lee C, Lee K, Pennings JM. 2001. Internal capabilities, external networks, and performance: a study on technology-based ventures. Strategic Management Journal 22(6-7): 615640. 
Luk CL, Yau OH, Sin LY, Tse AC, Chow RP, Lee JS. 2008. The effects of social capital and organizational innovativeness in different institutional contexts. Journal of International Business Studies 39(4): 589-612.

Lumpkin GT, Dess GG. 1996. Clarifying the entrepreneurial orientation construct and linking it to performance. Academy of Management Review 21(1), 135-172.

Lumpkin GT, Dess GG. 2001. Linking two dimensions of entrepreneurial orientation to firm performance: The moderating role of environment and industry life cycle. Journal of Business Venturing 16(5): 429-451.

Martín-Tapia I, Aragón-Correa JA, Rueda-Manzanares A. 2010. Environmental strategy and exports in medium, small and micro-enterprises. Journal of World Business 45(3): 266-275.

McGahan A. 2012. Challenges of the informal economy for the field of management. Academy of Management Perspectives 26(3): 12-21.

McGrath RG. 2013. The end of competitive advantage: How to keep your strategy moving as fast as your business. Harvard Business Review Press.

Miller D. 1983). The correlates of entrepreneurship in three types of firms. Management Science 29: 770-791.

Molina-Azorín JF, Claver-Cortés E, Pereira-Moliner J, Tarí JJ. 2009. Environmental practices and firm performance: an empirical analysis in the Spanish hotel industry. Journal of Cleaner Production 17(5): 516-524.

Mosakowski E. 2002. Overcoming resource disadvantages in entrepreneurial firms: When less is more. In Strategic entrepreneurship: Creating a new mindset, ed. M. A. Hitt, R. D. Ireland, S. M. Camp, and D. L. Sexton, 106-126. Oxford: Wiley-Blackwell.

Moyano-Fuentes J, Maqueira-Marín JM, Bruque-Cámara S. 2018. Process innovation and environmental sustainability engagement: An application on technological firms. Journal of Cleaner Production 171, 844-856.

Neutzling DM, Land A, Seuring S, do Nascimento LFM. 2018. Linking sustainabilityoriented innovation to supply chain relationship integration. Journal of Cleaner Production 172: 3448-3458

Nidumolu R, Prahalad CK, Rangaswami MR. 2009. Why sustainability is now the key driver of innovation. Harvard Business Review 87(9): 56-64.

Pissarides F. 1999. Is lack of funds the main obstacle to growth? EBRDs experience within small-and medium-sized business in Central and Eastern Europe. Journal of Business Venturing 14: 519-539

Plaza-Úbeda JA, de Burgos-Jiménez J, Carmona-Moreno E. 2010. Measuring stakeholder integration: knowledge, interaction and adaptational behavior dimensions. Journal of Business Ethics 93(3): 419-442. 
Podsakoff PM, MacKenzie SB, Lee J, Podsakoff N. 2003. Common methods biases in behavioral research: a critical review of the literature and recommended remedies. Journal of Applied Psychology 88(5): 879-903.

Powell TC, 1992. Organizational alignment as competitive advantage. Strategic Management Journal 13: 119-134

Quan Y, Wu H, Li S, Ying SX. 2018. Firm sustainable development and stakeholder engagement: The role of government support. Business Strategy and the Environment $; 1-14$.

Rauch A, Wiklund J, Lumpkin GT, Frese M. 2009. Entrepreneurial orientation and business performance: An assessment of past research and suggestions for the future. Entrepreneurship Theory and Practice 33(3): 761-787

Roxas B, Ashill N, Chadee D. 2017. Effects of entrepreneurial and environmental sustainability orientations on firm performance: A Study of Small Businesses in the Philippines. Journal of Small Business Management 55(S1): 163-178.

Roxas B, Chadee D. 2012. Environmental sustainability orientation and financial resources of small manufacturing firms in the Philippines. Social Responsibility Journal 8(2): 208226.

Roxas B, Coetzer A. 2012. Institutional environment, managerial attitudes and environmental sustainability orientation of small firms. Journal of Business Ethics 111(4): 461-476.

Schillo RS. 2011. Entrepreneurial orientation and company performance: can the academic literature guide managers?. Technology Innovation Management Review, 1(2).

Sheng S, Zhou KZ, Li JJ. 2011. The effects of business and political ties on firm performance: Evidence from China. Journal of Marketing 75(1): 1-15.

Shubham, Charan P, Murty LS. 2018. Secondary stakeholder pressures and organizational adoption of sustainable operations practices: The mediating role of primary stakeholders. Business Strategy and the Environment,1-14.

Sobel ME. 1982. Asymptotic confidence intervals for indirect effects in structural equation models. Sociological Methodology 13: 290-312.

Stinchcombe AL. 1965. Social structure and organizations. In J.G. March (Ed.), Handbook of organizations (pp. 142-193). Chicago, IL: Rand McNally College Publishing Company.

van Burg E, Podoynitsyna K, Beck L, Lommelen T. 2012. Directive deficiencies: How resource constraints direct opportunity identification in SMEs. Journal of Product Innovation Management, 29(6): 1000-1011.

Van Burg E, Romme AGL. 2014. Creating the future together: Toward a framework for research synthesis in entrepreneurship. Entrepreneurship Theory and Practice 38(2): 369-397. 
Varadarajan R, Kaul R. 2017. Doing well by doing good innovations: alleviation of social problems in emerging markets through corporate social innovations. Journal of Business Research.

Varadarajan R. 2017. Innovating for sustainability: a framework for sustainable innovations and a model of sustainable innovations orientation. Journal of the Academy of Marketing Science 45(1): 14-36.

Voss GBD. Sirdeshmukh, Voss ZG. 2008. The effects of slack resources and environmental threat on product exploration and exploitation. Academy of Management Journal 51 (1): $147-64$

Wiklund J, Shepherd D. 2003. Knowledge-based resources, entrepreneurial orientation, and the performance of small and medium-sized businesses. Strategic Management Journal 24(13): 1307-1314.

Wiklund J, Shepherd D. 2005. Entrepreneurial orientation and small business performance: a configurational approach. Journal of Business Venturing 20(1), 71-91.

Wiklund J. 1999. The sustainability of the entrepreneurial orientation-performance relationship. Entrepreneurship Theory and Practice 24(1), 37-48.

World Bank 2011. The Little Data Book on Africa 2011. Washington DC, World Bank.

York JG, O'Neil I, Sarasvathy SD. 2016. Exploring environmental entrepreneurship: identity coupling, venture goals, and stakeholder incentives. Journal of Management Studies, 53(5), 695-737. 
